\title{
INNOVATION IN FOREST POLICY AND ECONOMICS TEACHING AND RESEARCH ${ }^{*}$
}

\author{
Inovacije u nastavi i istraživanju politike i gospodarstva u šumarstvu
}

\author{
Franz Schmithüsen ${ }^{1}$
}

\begin{abstract}
The Bologna process thrusts forestry and forestry education into the context of an evolving global economy as well as worldwide concerns about environmental protection and climate change. It stimulates the integration of forestry into the framework of sustainable land-use practices and the combination of forest management experience with new scientific knowledge and research methodology. Forest professionals need a comprehensive educational background if they are to tackle rapidly changing social, economic and political problems. At the same time they need to understand the evolving and locally specific social and cultural aspects of forestry. This demands a joint approach to forest management, environment protection and landscape conservation. Maintaining the natural resource base and managing forests in a sustainable manner will require teaching programme combining policy and law, business economics and management, and forest resource and environmental economics components.
\end{abstract}

Keywords: Land use practices, natural resources protection, wood production, environmental services, forest ecosystem management

\section{Izvod}

Bolonjski proces predvidio je da šumarstvo i obrazovanje u šumarstvu budu u kontekstu razvijanja globalne ekonomije, i svjetsku pozornost fokusirano na zaštitu okoline i klimatske promjene. On stimulira integriranje šumarstva u okvire održive prakse korištenja zemljišta i kombinacije iskustava u gospodarenju šumama s novim znastvenim spoznajama i metodologijama istraživanja. Šumarskim stručnjacima potrebna je sveobuhvatna obrazovna osnovica ukoliko žele prihvatiti brze promjene na društvenom, ekonomskom i političkom planu. Istovremeno, neophodno je razumijevanje razvoja i lokalno specifičnih društvenih i kulturnih aspekata šumarstva.

\footnotetext{
* Invited Paper presented to the first West Balkan Conference on socio-economic teaching and research in forestry. Sarajevo.

${ }^{1}$ Swiss Federal Institute of Technology, ETH, Zurich - Švicarski Federalni Institut za Tehnologiju, ETH, Zurich
} 
Ovo zahtijeva udruženi pristup upravljanju šumama, zaštiti okoliša i konzerviranju okoliša. Održavanje baze prirodnih izvora i gospodarenje šumama na održiv način zahtijevat će nastavne programe koji će kombinirati politiku i zakonodavstvo, poslovnu ekonomiju i gospodaranje, uključujući komponente šumskih resursa i gospodarenje okolišem.

Ključne riječi: praksa korištenja zemljišta, zaštita prirodnih resursa, proizvodnja drveta, ekološke usluge, upravljanje ekosistemom šume.

\section{Introduction - Uvod}

The Bologna process presents an opportunity to foster innovation, cooperation and competition in science. It establishes a common ground for university teaching and research in Europe by introducing comparable academic grades and quality standards. It encourages mobility among students, teachers and researchers worldwide and adopts a three-cycle educational system with the accumulation and transfer of credits, as in North America. The Bologna process offers a chance to modernize the content and subjects of forestry teaching, to expand socio-economic empirical research on environmental and natural resources management, and to link teaching and research more closely to the applied natural sciences. This means, foremost, putting more emphasis on societal problems and restructuring and expanding the contribution of the social sciences in university forestry curricula, particularly in the fields of forest policy and forestry economics.

The importance of this process has to be seen in the broader perspective of evolving and changing relevance of science, research and academic teaching, as well of the political dimension of knowledge. A significant aspect in this context is the social and political complexity of scientific problems and of the practical consequences which result from scientific findings. This complexity requires increasingly interdisciplinary and trans-disciplinary approaches in research and teaching generating different kinds of knowledge production and leading to a new social contract between science and society (GIBBONS ET AL. 1994; NOWOTNY ET AL. 2001).

The line between different academic disciplines, between fundamental and applied research, and between public and private industrial research becomes more fluent. Broader political and economic networks with multiple institutional links develop in teaching and research develop addressing pressing social and environmental problems and engaging a more open dialogue between citizens, non-governmental organisations and governmental institutions. Universities and public research agencies move from a largely autonomous process of producing scientific findings and providing academic knowledge to a more dialogue oriented discourse with industry and the public (SHINN 2002). Science is transformed gradually into a productive force generating new income and scientific knowledge becomes more strongly a competitive input factor for social change and economic and technological development (ETZKOWITZ 2001). 


\section{System approach in sustainable utilization of renewable natural resources Sistemski pristup održivom korištenju obnovljivih prirodnih resursa}

The design of innovative socio-economic teaching and research programmes in forestry must be based on the specifics of managing renewable natural resources. The focus of such programmes should be on:

- sustainability as the guiding principle for maintaining and developing the natural resource base;

- multifunctional and locally adapted land management solutions that address increasing economic, societal and environmental demands;

- interplay between natural processes, technological solutions, societal behaviour and political decision making;

- improvements in land management through developing effective institutions and involving stakeholders;

- use of appropriate market-based instruments and coordinated public policy networks; and

- multidisciplinary approaches among the natural and social sciences that lead to a common scientific basis in dealing with economic development, societal needs and values, and cultural change.

Figure 1 provides a schematic presentation of a system approach to analysing the conditions for sustainable management, protection and preservation of the renewable natural resource base. The $y$ dimension shows the dynamics of social change and the driving factors that determine the prevailing use of renewable natural resources. Significant aspects are cultural values, societal demands, economic needs and opportunities; political and legal networks setting the conditions for resource use; and decision-making processes involving landowners, land users and other stakeholders. The $x$ dimension indicates the spatial impacts of resource use and management on the physical and human environment as a whole, at landscape levels, for different land-use categories and individual land management units. The $z$ dimension presents the interplay between private and public goals, available technologies, policy instruments, and the feedbacks and results that are obtained.

A second aspect of a systems approach of natural resources management in a broad social, environmental and land-use perspective is the historical dimension of change. It is, in fact, my firm conviction that the structure and content of any academic teaching and research programme should be anchored in a profound understanding of the long-lasting cultural processes that have influenced man's varied uses of natural resources over centuries and shaped the landscapes in which he lives (SCHMITHÜSEN AND SEELAND 2006). This understanding will enable professionals, educators and researchers to be aware of the dynamic human interactions and the manifold societal 
impacts on the physical environment and on land management. Only the cultural context can explain the great variety of problems and solutions in time and space as well as the need to develop new solutions once that the frame-conditions have changed. Forest teaching and research should enable university graduates and future engineers to grasp the dynamics of cultural change and their meaning for societal demands on forests and forestry. Students need integrative social and cultural knowledge to assess opportunities and new approaches in managing natural resources in a specific situation and at a given time.

Forest and landscape dynamics are the result of complex interactions between physical and ecological conditions and changing impacts from societal needs and values, new economic opportunities, and evolving political institutions. Social, economic and political processes have evolved and become multilayered. This requires an integrative view of forest systems addressing the multiple and spatially differentiated uses of forests as an important part of renewable natural resources. Research and teaching need to become more interdisciplinary as has been the case in the past. It has to combine material flow analysis of natural resources use with the analysis of the prevailing economic, social and political systems as well as of the structural agents determining private and public decision making on man's environment and natural resource base (BINDER 2007a, 2007b). In order to get a better understanding of the continuously changing interactions of human-environment systems a scientific approach combining natural and social sciences need to be put on an equal footing. Research methods integrating quantitative and qualitative knowledge combined with case studies providing empirical insight on concrete decision making problems and solutions are of particular interest in this context (SCHOLZ AND TIETJE 2002).

\section{Teaching requirements in forest policy and law Zahtjevi u nastavi o politici i zakonodavstvu u šumarstvu}

Public policies and law provide the necessary political framework for balancing private and public interests and are changing in response to new societal demands. No longer is it sufficient to address only wood production and forest protection and management. Today's social and environmental demands and policy objectives extend to human induced effects on climate change, preservation of biodiversity, and to nature and landscape protection. National and local political problems have to be addressed, as well as the continental and worldwide concerns of citizens and governments. The fundamentally new aspect of forest related policy decision making is that it must devote equal attention to economic efficient wood production, societal and cultural values, and environmental protection. 
Figure 1: Human environment systems interactions in sustainable natural resources management

Slika 1: Interakcija humanih sistema u okolišu u upravljanju održivim prirodnim resursima

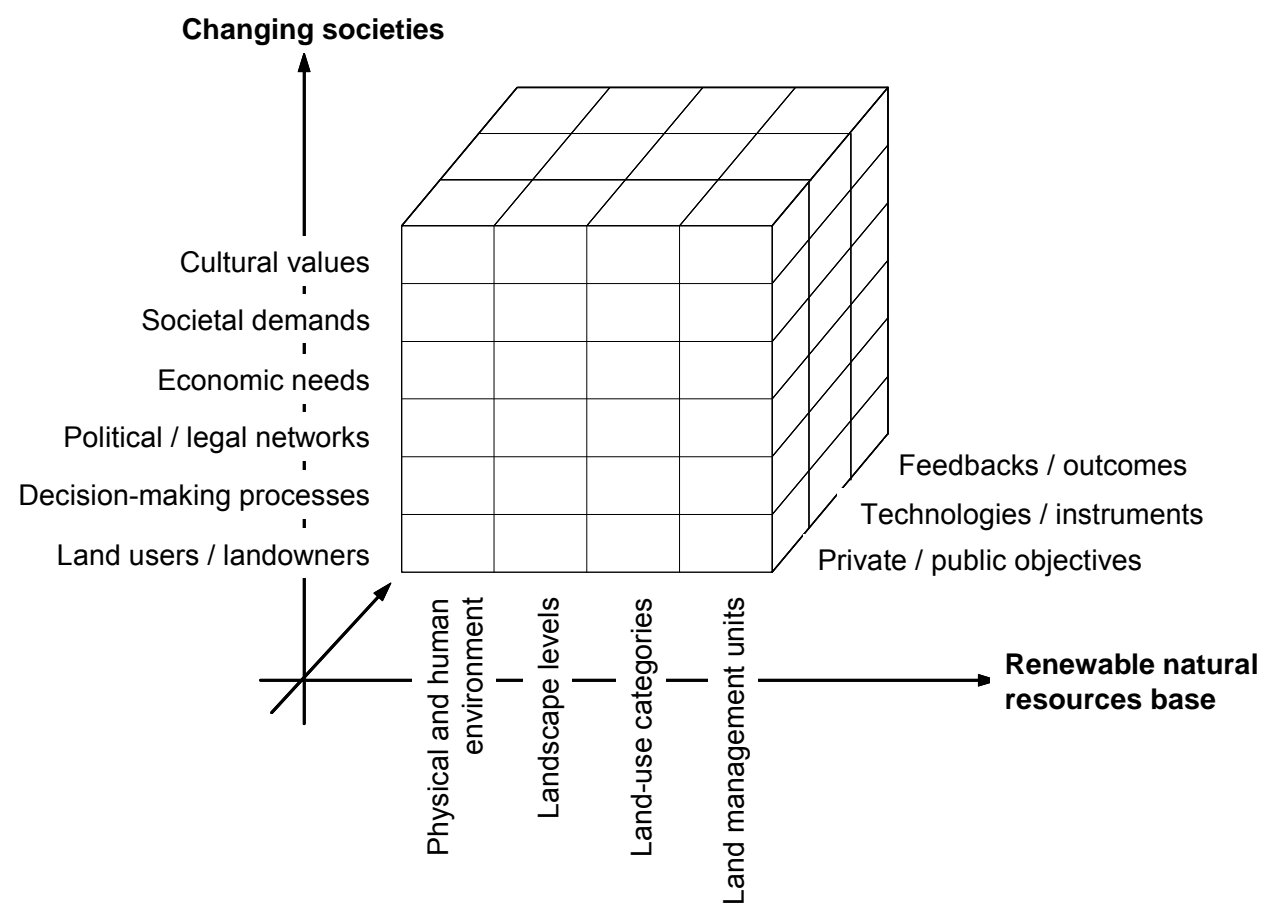

Source: SCHMITHÜSEN 2004, p. 96, modified

Forest policy goals are incremental and involve the economic potential of forests for industrial wood production and processing, their availability as multifunctional social resources in urban and rural areas, their importance as varied and complex ecosystems, and their essential role in maintaining biodiversity of flora and fauna. The process of modernizing national forest policies and legislation has gained considerable momentum across Europe-western, central, and eastern - since the 1990s. In countries in transition to open civil society and market economies, functioning democratic institutions are being built, and new political and legal frameworks addressing agriculture and forestry, nature preservation and environmental protection are being established (CIRELLI AND SCHMITHÜSEN 2000; SCHMITHÜSEN 2003b).

Figure 2 shows a systems approach to identifying the broad regulatory issues and content of forest policy and law. Protection regulations refer to conserving and preserving the environment and biodiversity, nature and landscapes, soil and water resources, and the cultural and spiritual values associated with trees and forests. Landuse regulations provide for zoning of forestland, control of forest clearing, protection 
of a country's permanent forest estate, and the establishment of new forest resources through reforestation and afforestation. Utilization and management regulations determine the rights and responsibilities of forest owners with regard to the sustainable production of wood and non-timber forest products, environmental and recreational services, and multifunctional forest use and management systems.

Figure 2: Forest policy and law regulations

Slika 2: Politika i zakonodavstvo u šumarstvu

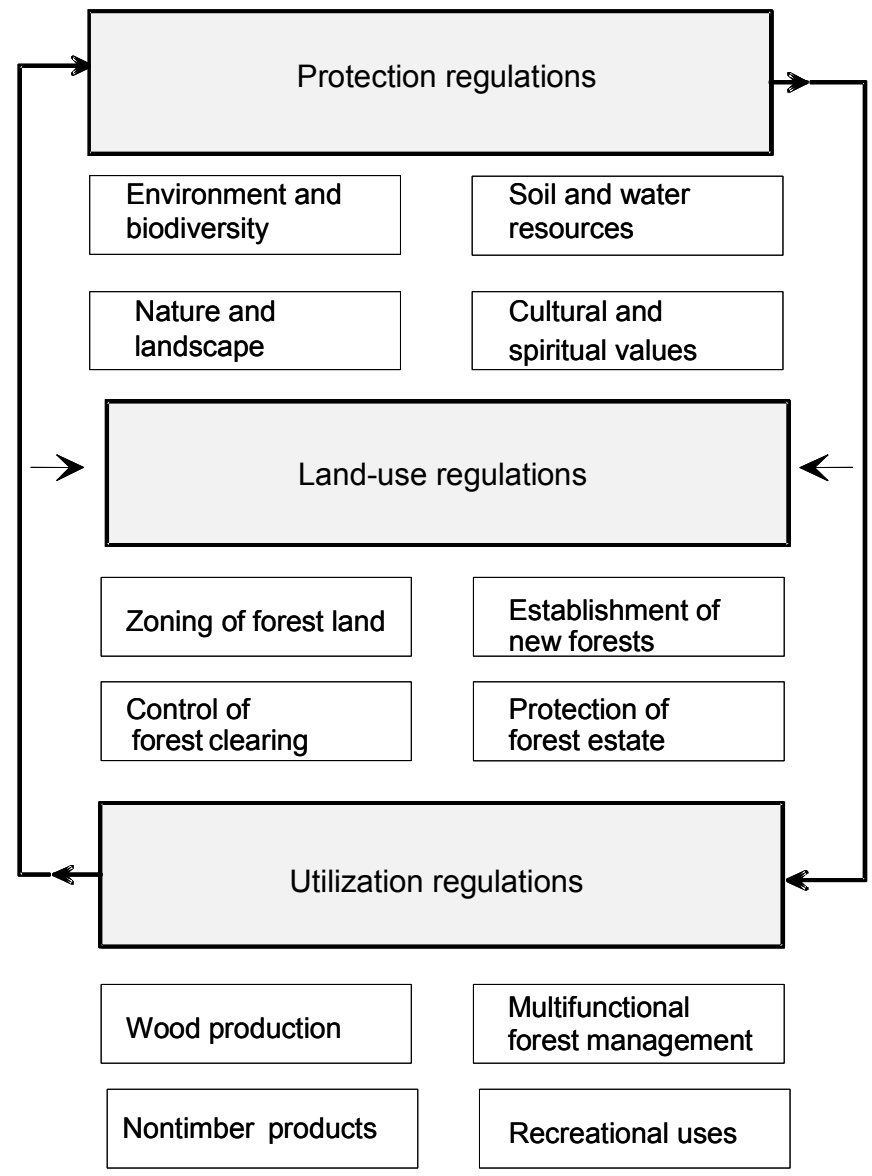

Source: SCHMITHÜSEN 2003a, p. 10

Forest policy has been a traditional university course since the 19th century, when university forestry programs were established. However, the focus of modern policy teaching and research needs to be based much more on the disciplinary foundations of the political sciences than has generally been the case. Education in this field must 
combine knowledge of political science concepts, models and methodologies with analysis of political decisions about forestland management options in the context of protecting the environment and addressing climate change. New scientific concepts and methodologies are available, new research is going on, and the literature is continually growing. The challenge is to combine specific knowledge of forestry problems with a strong methodological foundation in political science. A wealth of forestry-specific knowledge has been accumulated in the past that can be used for demonstration and problem analysis of the problems of today. It is essential to use this knowledge in a more comprehensive educational and research context.

Primary teaching subjects in a modern forest policy course relate to the following broad themes:

- Forest conservation, protection and management are economic, political, social and cultural phenomena, and sustainability is the basis for maintaining and utilizing natural renewable resources.

- Important conflicts over forests exist between divergent private and public interests. Such conflicts relate to controversial strategies and management goals for industrial wood production, protecting the environment, and nature and landscape preservation.

- Forest policy as well as other forest related public policies form an aggregate of multiple conflict regulation processes and imply a multitude of political arbitration and decision-making processes among private and public stakeholders in utilizing the forest resource.

- Political systems and constitutional values, political institutions and political actors, and law and jurisdiction are the foundation of political arbitration and decision-making processes.

The students need a solid knowledge of the functioning of the political system in a democracy and the constituting political steps determining changes in forest policy and law, as for that matter, in other political domains such as energy, water, environmental and landscape policies. The political framework for the formation of a particular public policy and for its implementation can be analysed in three fundamental dimensions. The institutional dimension (polity) determines the constitutional framework for political decisions. The process dimension (politics) identifies the policy actors (stakeholders), their interests and conflicts, their political power, and ways to resolve conflict. The policy dimension deals with concrete political problems and solutions, addressing specific needs and values and determining goals and measures. It is important to understand the policy cycle, the choice of policy instruments, and the role of public policy programmes.

Governance has become important in politics as a reaction to policy failures due to rigid and ineffective top-down decisions of the state. The word denotes a shift from 
hierarchic and top-down political processes to a more participatory and self-organizing style of policy making. It thus characterizes a more open and democratic relationship between the state and civil society, including citizens, stakeholders, and private institutions such as associations, corporations and social communities. Policy actors in this context include concerned interest groups, private enterprise and industry representatives, and nongovernmental organisations (NGOs). Active communication among all actors within the political system and processes leading to formally agreed problem solutions are essential elements of modern governance. And governance becomes operational through market transactions, societal self-regulation, negotiation processes and agreement on criteria, indicators and performance standards, as well as through contractual arrangements for the delivery of goods and services.

Governance is based on functioning political networks between the public and private sector, including the following:

- cooperation between the state and specific target groups;

- participation of citizens and NGOs in the processes of policy making and policy implementation;

- coordination, inclusiveness and integration of relevant sector policies;

- multilevel transactions between private and public organizations;

- decentralization and transfer of public authority and responsibilities to lower governmental levels in accordance with the principle of subsidiarity;

- programmes based on jointly agreed and precise objectives, monitoring of performance and evaluation of results; and

- business standards for public administration to ensure effectiveness and efficiency.

Another important aspect in modern forest policy teaching results from the fact that there are transversal and cross-sectoral public policies and regulations that have multiple impacts on forest and natural resource utilization-sometimes conflicting with the overall goals of sustainability and rational use of the natural resource base (Figure 3). Public policies of relevance in this context may address agriculture, game management and fisheries and the protection of public and private infrastructure. Also having a growing impact on forestry are policies dealing with nature preservation, landscape protection, national parks, environmental protection and soil and water resources. Policies addressing rural development, land-use planning, land tenure, regional development, recreation and tourism have considerable influence on forest utilization as well.

It follows that forest policy alone cannot regulate exclusively anymore the public framework for using and managing forests. It is important to analyse the full range of 
relevant public policies and political interventions enhancing their positive impacts on forest conservation and forestry development, as well as reducing those policy effects having negative effects on forest development. A more systematic consideration of cross-sectoral effects and policy links has been one of the important concerns of the international community since the Rio Conference 1992 and its follow-up processes.

Figure 3: Multiple public policy impacts on forest resource utilization

Slika 3: Višestruki utjecaj javne politike na korištenje resursa u šumarstvu

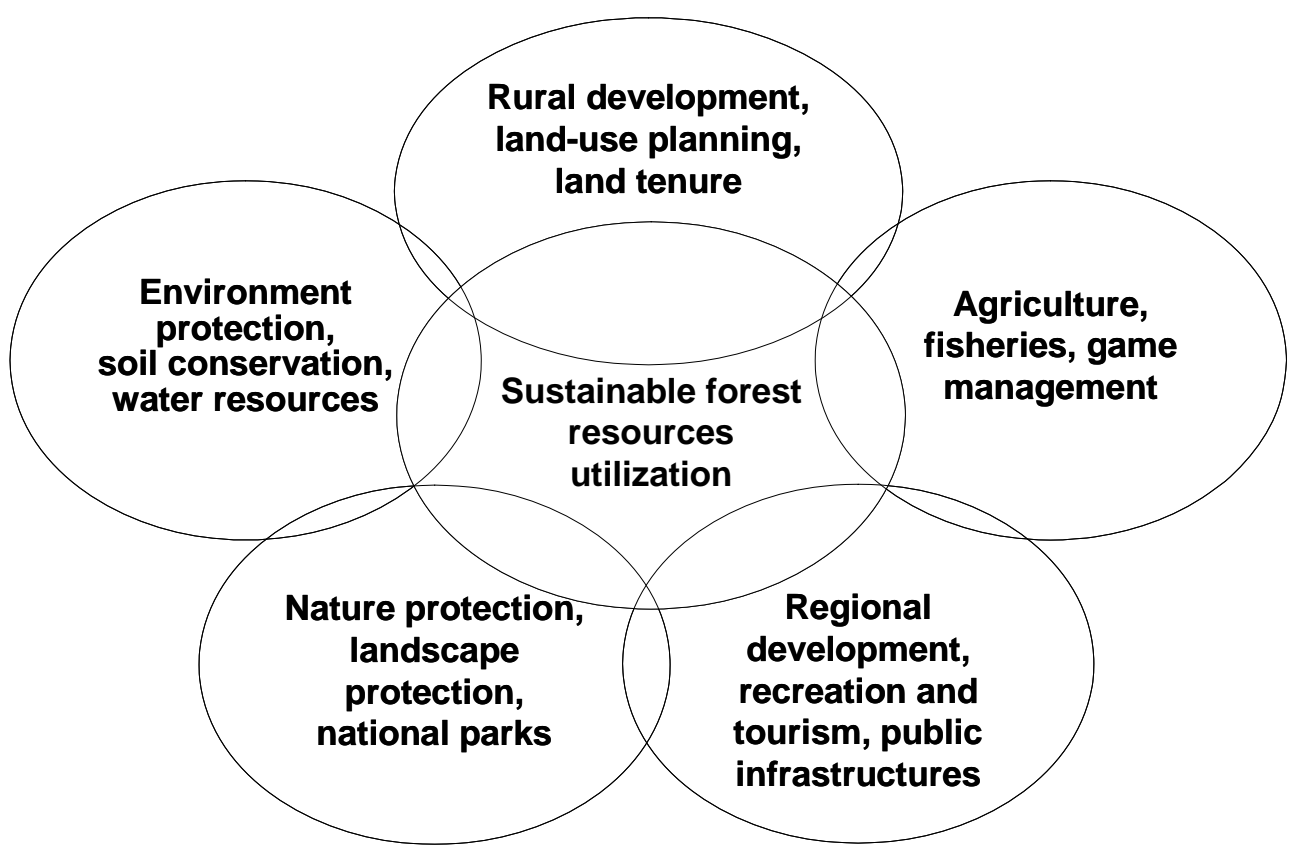

Source: Schmithüsen 2003a, p. 13, modified

National and international governance networks addressing sustainable forest management, environmental protection and natural resource utilization are today increasingly of a multilevel political nature. They extend from the global level of the United Nations and from continental and supranational levels, such as the European Union, to the national level, sub-national levels in countries with federal political systems, and to municipal and local community and association levels. The combined demands on forest management from such multilevel policy making must be met foremost by landowners and land users, and the political impacts on forestry have to be assessed for individual ownership units, ecosystems and the landscape. 


\section{Teaching requirements in forest business economics - Nastavni zahtjevi $u$ poslovnoj ekonomiji u šumarstvu}

Sustainable wood production remains the backbone of commercial forestry practices and of a sustainable forest sector. New technology offers opportunities to improve the productivity and profitability of wood production through rationalization and reduction of production costs, and efficient business management must focus on the entire value-added chain between forestry activities, industrial wood processing and changing end-markets demands. Innovative business and management teaching in forestry will explore the ongoing modernization of industrial production units based on comprehensive, cost-effective strategies. European wood-processing sector is already now highly competitive in world markets and expanding rapidly. If the industry succeeds in building on its present strengths and reducing its weaknesses, sustainable wood production and modern wood-processing technologies can deliver new products and services to intermediate end-user markets.

Multifunctional land management is an established land management practice generates additional income from marketable environmental and recreational services. Forestry students and professionals thus have to understand the economics of industrial wood processing as well as the economics of multifunctional land management. It is concerned with actual and prospective business opportunities and a wide range of present and future consumer wants and preferences as the driving forces within a market economy. The analysis focuses on short- and medium-time perspectives and on economic growth in a spatial perspective reaching from local to national and to international.

The programme in forest business economics requires a comprehensive disciplinary foundation in the concepts, models and methodologies of the management and economics sciences. It has to convey an understanding of the special production and marketing conditions within forestry and the wood-processing sector. And it should be well grounded in the current literature as well as the results of applied economic research. Development of an entrepreneurial spirit, strategic thinking and human relations abilities are the main goals in teaching the students. Primary subjects are the end markets that drive business, process management and strategic innovation techniques, measures to foster competitive wood production, and new approaches in marketing environmental and recreational services. Students, teaching staff and professionals need to understand the complex management processes of enterprises in a free-market economy. They have to know how to optimize production within the entire value-added chain and to understand the primary role of markets and marketing. At the same time they should be able to evaluate the options and constraints of industrial production of the wood industry versus multifunctional forestry production systems providing a wide range of goods and services. 
Figure 4: From sellers' to buyers' markets

Slika 4: Od tržišta prodavca do tržišta kupca

\begin{tabular}{|l|l|l|}
\hline & \multicolumn{1}{|c|}{ Seller' Markets } & \multicolumn{1}{c|}{ Buyer' Markets } \\
\hline Development Stage & Economy of scarcity & Economy of surplus \\
\hline $\begin{array}{l}\text { Relationship of } \\
\text { offer to demand }\end{array}$ & $\begin{array}{l}\text { Demand > offer } \\
\text { Client more active than } \\
\text { producer (excess demand } \\
\text { or deficit in supply) }\end{array}$ & $\begin{array}{l}\text { Demand < offer } \\
\text { Producer more active } \\
\text { than client (supply } \\
\text { surplus) }\end{array}$ \\
\hline Limiting factor & $\begin{array}{l}\text { Production of goods and } \\
\text { services }\end{array}$ & $\begin{array}{l}\text { Selling of goods and } \\
\text { services }\end{array}$ \\
\hline $\begin{array}{l}\text { Primary effort of } \\
\text { enterprise }\end{array}$ & $\begin{array}{l}\text { Rational use and expansion } \\
\text { supply and production } \\
\text { capacity }\end{array}$ & $\begin{array}{l}\text { Stimulation of demand } \\
\text { and focusing of } \\
\text { preferences on own } \\
\text { market offer }\end{array}$ \\
\hline $\begin{array}{l}\text { Long-term focus of } \\
\text { basic entrepre- } \\
\text { neurial function }\end{array}$ & Logistics and technology & Markets and marketing \\
\hline
\end{tabular}

Source: Peters et al. 1999, p. 133, translated

The fundamental change in modern market economies is the change from sellers' to buyers' markets (Figure 4). From an economy of scarcity, in which demand surpassed the available offer, we have moved in many countries to an economy of surplus, in which the offer exceeds apparent demand. Whereas production of goods and services was the limiting factor in the past, developing new markets for new products is now the primary issue. Stimulating demand and focusing on consumer preferences have become the driving forces of competitive business activities. New product development and design to meet new consumer wants and preferences and identification of new market segments and regions are now the entrepreneurial challenge.

A SWOT (strengths and weaknesses, opportunities and threats) analysis of the woodprocessing sector was undertaken by the European Community in 2000. The strengths lie in an expanding raw materials basis, the availability of high-level technology and expertise, access to large and sophisticated markets, and a high density of industrial clusters. Weaknesses are the high costs of raw materials and labour, insufficiency of entrepreneurial research and development, resistance to restructuring and rationalization of business, and in many European regions, lack of a wood-using culture. New opportunities include the promotion of wood and wood products as "lifestyle products," development of integrated solutions in construction and building, use of geographic and infrastructural advantages in expanding markets, and transfer of 
production activities to cost-competitive regions. Threats are in particular global competition, lack of innovation in products and services, and competition from other high-tech materials.

Important standard chapters of management and economics to be included in this programme are business politics, human resources and organisational development, accounting systems and methods, financing and investment, logistics and production processes, and strategic planning and controlling. The translation and subsequent publication by the economics faculty of the University in Belgrade of Entrepreneurship in the Forest and Wood Products Industry - Principles of Business Economics and Management is based on the original version in German, published in 2003 as a leading textbook and reference in our field (SCHMITHÜSEN ET AL. 2003c). The book can make a significant contribution in modernizing the teaching programmes of the forestry faculties in the Balkan region. The authors hope that the book will be a standard teaching text for bachelor's and master's students as well as a standard reference for forestry and wood-processing professionals. We are thankful to all colleagues who have contributed to make this publication a reality. Special thanks are due to the capable translator, Vesna Ivanovic, and to Assistant Professor Dragan Nonic for his initiative and valuable contributions.

Another important issue, to be addressed in teaching and research, is the need to develop financial strategies for multifunctional forest management practices providing multiple forest goods and services. Combined forest financing is based on the principle that the private and public interests using the resource must share costs and benefits equally. Figure 5 presents a systems approach in identifying investments and current financial contributions for multifunctional forestry. It indicates different combinations of wood production, non-timber forest products, and environmental and infrastructural services. Proceeds from market transactions are the backbone for financing forestry operations. They derive from sales of wood and non-timber products, technical services for third parties, and environmental and infrastructural services for which markets exist or can be developed. Proceeds from third parties result from contractual obligations and payments made by individual users, private user groups and NGOs for specific services and may include incentives and compensation for protecting infrastructural facilities or for preserving forest areas with high ecological values.

National, sub-national and local authorities may provide similar incentives and compensation: for instance, for managing protection forests under a special regime, for nature and landscape protection, or for environmental services provided in the public interest. Supranational and international institutions and organisations, such as the European Union, may create special programmes to co-finance structural improvements for productive forest resource development through afforestation and reforestation, and for fire prevention, detection and suppression. Cooperation among small-scale landowners in sustainable management practices and rural development 
measures intended to enhance the self-sufficiency of the local population provide other possibilities to finance joint public and private multifunctional forest management systems.

Teaching requirements in forest resources, environmental and ecological economics - Nastavni zahtjevi $u$ oblasti šumskih resursa, okoliša $i$ ekonomije/gospodarstva okoliša

Decision making of landowners and land-users play a decisive role in determining whether the renewable natural resource base is maintained or degraded (Figure 6). Forest owners have both the right and the responsibility, considering the range of actual and potential societal and economic demands, to decide on management goals and forestry practices. Forestry professionals must be aware of the economic needs and opportunities that influence forest owners' use and management. But it is also important to grasp the social and cultural values that prevail at any given time and understand their implications for a particular locality, country or region. Promoting sustainable uses of the natural resource base is today the overarching goal of political interventions. Technology, investment and labour determine the level and combination of goods and services that can be made available to private consumers and the community as a whole.

Resource economics, environmental economics and ecological economics are three economic disciplines that widen the perspective, understanding and professional qualifications of university graduates. The concepts and methodologies of these disciplinary approaches offer a solid basis for teaching economics in the field of sustainable forestry and renewable natural resources management. Combining their theoretical concepts and methodologies in a problem-oriented research and teaching approach helps students understand the complex and pressing issues of society with regard to forest utilization, ecosystem management and the role of forests in maintaining a livable environment. The teaching focus is on understanding in a reasoned and scientific manner the economic values related to sustainable use and management; analysing human behaviour toward forests, nature and landscape in economic terms; and developing economically efficient solutions for a wide range of ecological problems.

Resource economics deals with optimization of production and consumption processes in a dynamic and intertemporal allocation perspective. Resource economists develop models of the conditions for an optimal consumption of resources and for correcting suboptimal consumption practices. Environmental economics analyses in particular the positive and negative external effects of production and consumption and how to internalize these externalities to improve utilization processes. 
Figure 5: Financing multifunctional forest management for wood, non-timber products and environmental services

Slika 5: Finansiranje multifunkcionalnog upravljanja u šumarstvu, za drvo, ne-drvne proizvode i usluge u okolišu

\begin{tabular}{|c|c|c|}
\hline \multicolumn{3}{|c|}{ Investment and financial contributions from landowners } \\
\hline Owners' uses and consumption & & aterests and values \\
\hline \multicolumn{3}{|c|}{$\begin{array}{l}\text { Proceeds from market sales } \\
\end{array}$} \\
\hline $\begin{array}{l}\text { Wood and nonwood } \\
\text { products }\end{array}$ & $\begin{array}{l}\text { Marketable } \\
\text { environmental services }\end{array}$ & $\begin{array}{l}\text { Marketable infrastructure } \\
\text { services }\end{array}$ \\
\hline \multicolumn{3}{|c|}{ Proceeds from contractual contributions and compensation of third parties } \\
\hline Individual users & Private user groups & NGOs \\
\hline \multicolumn{3}{|c|}{$\begin{array}{c}\text { Proceeds from incentives and compensation of national governments, } \\
\text { subnational and local authorities }\end{array}$} \\
\hline $\begin{array}{l}\text { Incentives for goods and services } \\
\text { delivered as public requirements }\end{array}$ & & $\begin{array}{l}\text { Compensation for goods and services } \\
\text { made available in the public interest }\end{array}$ \\
\hline \multicolumn{3}{|c|}{$\begin{array}{c}\text { Proceeds from supranational and international institutions and } \\
\text { organizations }\end{array}$} \\
\hline $\begin{array}{c}\text { Productive resources } \\
\text { development }\end{array}$ & $\begin{array}{l}\text { Sustainable land } \\
\text { management practices }\end{array}$ & $\begin{array}{l}\text { Protection and nonuse } \\
\text { arrangements }\end{array}$ \\
\hline
\end{tabular}

Source: SCHMITHÜSEN 2003a, p. 36, modified

It is primarily based on a static resources allocation analysis dealing with actual competitive use of environmental resources. Ecological economics deals with dynamic systems in evolution and with human preferences reflecting broad ecological opportunities and aversion to environmental constraints. The timeframe of the processes studied extends from short to very long, and its scale extends from local to global, and the focus is on sustainability as a combination of economic, environmental and social factors.

Primary teaching subjects encompass the following:

- multiple cross-sectoral links as well as positive and negative conditionality between economic decisions and their impacts on natural environmental processes, especially on soil, water and climate; 
- intertemporal effects of alternative use and management strategies on present as well as future stocks of renewable natural resources;

- economic implications of positive and negative externalities in production and consumption as influencing the behaviour of firms and individuals;

- economic and social aspects of providing public goods and managing common property resources to meet collective economic, societal and political demands and respect culturally derived attitudes and beliefs;

- dynamics of changing private and public consumer demands based on an optimization of economic strategies combining production, protection and preservation outputs;

- identification, quantification, valuation and monetarization of environmental, social and cultural services and benefits that result from multifunctional forest management, environmental protection, and nature and landscape preservation.

Figure 6: Drivers of the behaviour of landowners and land users Slika 6: Pokretači ponašanja vlasnika zemljišta i korisnika zemljišta

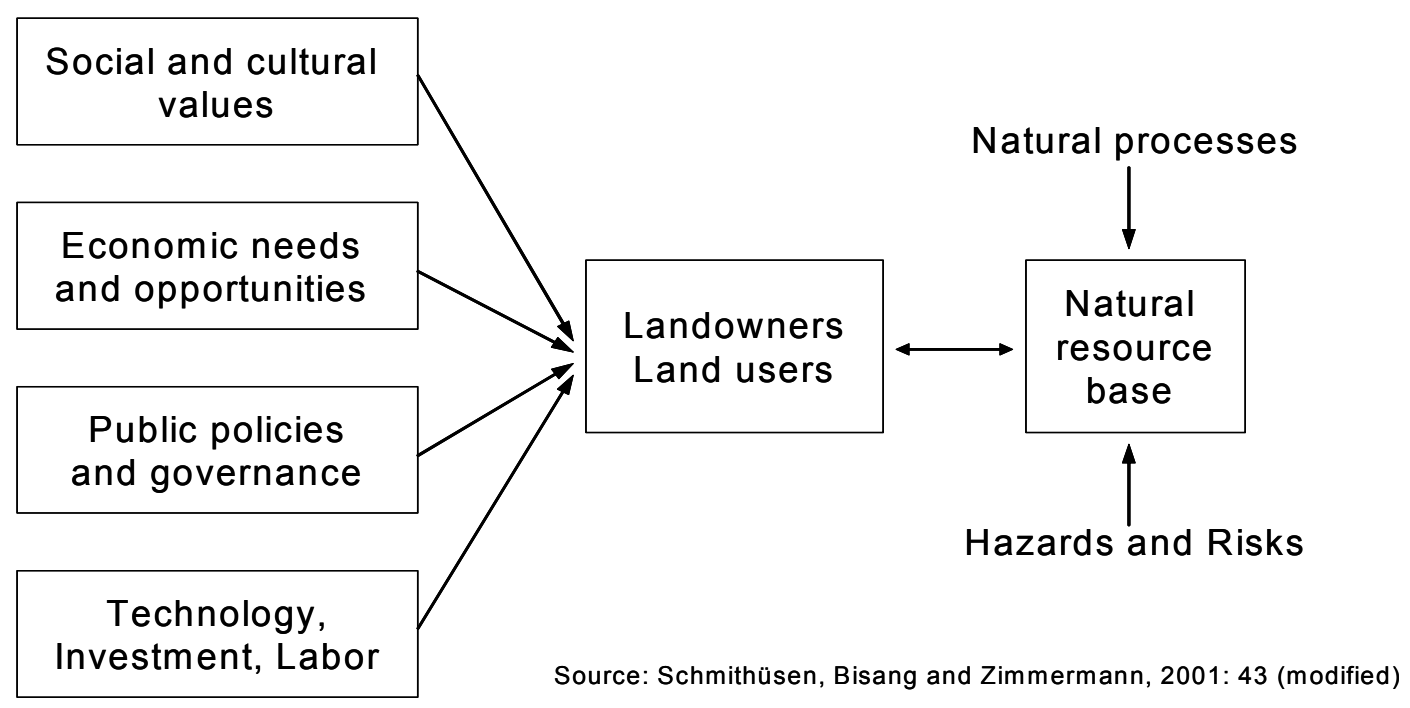




\section{Conclusions - Zaključci}

Exploring the dynamically changing relationships between forest, landscape and society requires empirical analysis and concrete experience in a given space and time with the aim of better understanding the prevailing institutional conditions, the ongoing political and social processes, and the actors involved. In investigating such relationships one comes to understand the interface between alternative land uses at different spatial scales as well as the societal changes that determine the manifold interactions. One has to understand the many possible interactions between the production of private goods and services from natural renewable resource base on the one hand, and the economic and political management requirements for sustaining a continuous flow of private and public goods, services and cultural values from available physical resource potential on the other hand. A comprehensive research approach is essential for understanding the multiple and varying dimensions of relevant outputs from forestry and for achieving a rational distribution of investments and maintenance costs among those benefiting from wood production and environmental services.

With regard to innovation in forest policy and forest economics teaching and research specifically, the following conclusions are to be emphasized:

- Academic teaching of socio-economic aspects in forestry curricula needs to be based on a systems approach, analysing forestry problems in the overall context of natural resource use, sustainable land management practices and environmental protection.

- Forest policy teaching requires a solid disciplinary basis in the theoretical concepts, models and research methodologies of political science. Academic courses in forest policy and forest law should offer, for instance, a comprehensive knowledge of public policy making, governance networks and multilevel political processes.

- Forest economics related to private and public land management should focus on a comprehensive understanding of entrepreneurial decisions and management strategies. Knowledge of business economics, analytical skills, social capabilities and leadership are primary teaching goals.

- Professional foresters need to understand public values related to environmental, recreational and landscape services. The leading concepts, theories and research methodologies of resource economics, environmental economics and ecological economics, as they relate to the use and management of forests, have to be included in forestry curricula.

- Social and cultural developments in modern societies as well as the historical dimensions of societal changes in attitudes towards forests are an integrating 
part of academic programmes for university forestry students. Knowledge of the dynamic changes in humans' relationship to forests, nature and environment is the primary focus of teaching.

\section{References - Referentna literatura:}

1. BINDER, C. R., 2007a: From Material Flow Analysis to Material Flow Management - Part I: Social Sciences Modeling Approaches Coupled to MFA. Journal of Cleaner Production 15 (2007) 1596-1604.

2. BINDER, C. R., 2007b: From Material Flow Analysis to Material Flow Management - Part II: The Role of Structural Agent Analysis. Journal of Cleaner Production (2007) 15 1605-1617

3. Cirelli, M.-T.; SchmithÜSEN FR., 2000: Trends in Forestry Legislation: Western Europe. FAO Legislative Study 10, Rome. http://faolex.fao.org/faolex/index.htm

4. Etzkowitz, H., 2001: The Second Academic Revolution and the Rise of Entrepreneurial Science. IEEE Technology and Society Magazine, Summer 2001.

5. European Commission, 2000: Competitiveness of the European Union Woodworking Industries - Summary Report. Office for Official Publications of the European Communities, Luxembourg. 72 pp.

6. Gibbons, M.; Limoges, C.; Novotny, H.; Schwartzmann, S.; Scott, P.; Trow, M., 1994: The New Production of Knowledge. London, Sage.

7. Novotny, H.; ScotT, P.; GibBOnS, M., 2001: Re-Thinking Science Knowledge and the Public in an Age of Uncertainty. London, Polity Press with Blackwell Publishers.

8. Peters, S.; Fortgeführt von Bruehl, R. M. AND J. N. Stelling, 1999: Betriebswirtschaftslehre - Einführung. 9. durchges. Auflage. Oldenbourg, München. 239 S.

9. SChMithÜSEn, F.; BisAnG, K.; ZimMermanN, W., 2001: Cross-Sector Linkages in Forestry - Review of Available Information and Considerations on Further Research. Working Document No 1; Forestry Department; FAO, Rome. 56 pp.

10. SChMithÜSEN, F., 2003a: Understanding Cross-Sectoral Policy Impacts Policy and Legal Aspects. In: Cross-sectoral Policy Impacts between Forestry and other Sectors. FAO Forestry Paper 142: 5-44 (2003); FAO, Rome.

11. SCHMithÜSEN, F., 2003b: The Global Revolution in Sustainable Forest Policy - A European Perspective. Pinchot Lecture Series; Pinchot Institute for Conservation, Washington D.C. 
12. SchmithüSen, F.; Kaiser, B.; Schmidhauser, A.; Mellinghoff, St.; KAMMERHOFER, A. W.; 2003c: Unternehmerisches Handeln in der Wald- und Holzwirtschaft - Betriebswirtschaftliche Grundlagen und Managementprozesse. Deutscher Betriebswirte-Verlag, Gernsbach. 560 S.

13. SchmithÜSEN, F., 2004: European Forest Policy Developments in Changing Societies: Political Trends and Challenges to Research. In: Towards the Sustainable Use of Europe's Forests - Forest Ecosystem and Landscape Research: Scientific Challenges and Opportunities. EFI Proceedings No. 49: 87-99, European Forest Institute, Joensuu, Finland.

14. SchmithÜSEN, F.; SeElAND, K., 2006: European Landscapes and Forest as Representation of Culture. In: Cultural Heritage and Sustainable Forest Management - The Role of Traditional Knowledge; Volume 1: 217-224 (2006), Ministerial Conference on the Protection of Forests in Europe, Liaison Unit, Warsaw, Poland.

15. Schmithüsen, F.; Kaiser, B.; Schmidhauser, A.; Mellinghoff, St.; KAMMERHOFER, A. W.; 2006: [Entrepreneurship in the Forest- and Wood Products Industry - Principles of Business Economics and Management]. Publishing Centre of the Faculty for Economic Sciences, University of Belgrade, Serbia. 529 pp. (Serbian Translation of the Text- and Reference Book in German published in 2003, Deutscher Betriebswirte-Verlag, Gernsbach.)

16. Scholz, R. W.; TIETJE, O., 2002: Embedded Case Study Methods Integrating Quantitative and Qualitative Knowledge. Thousand Oaks, London, New Delhi; Sage Publications.

17. SHINN, T., 2002: The Triple Helix and New Production of Knowledge Prepackaged Thinking on Science and Technology. Social Studies of Science 32/4 (August 2002) 599-614.

\section{SAŽETAK - Summary}

Bolonjski proces predvidio je da šumarstvo i obrazovanje $u$ šumarstvu budu u kontekstu razvijanja globalne ekonomije, i svjetsku pozornost fokusirao na zaštitu okoline i klimatske promjene. On stimulira integriranje šumarstva u okvire održive prakse korištenja zemljišta i kombinacije iskustava u gospodarenju šumama s novim znanstvenim spoznajama i metodologijama istraživanja. Šumarskim stručnjacima potrebna je sveobuhvatna obrazovna osnovica ukoliko žele prihvatiti brze promjene na društvenom, ekonomskom i političkom planu. Istovremeno, neophodno je razumijevanje razvoja i lokalno specifičnih društvenih i kulturnih aspekata šumarstva. Ovo zahtijeva sistemski pristup gospodarenju šumama, zaštiti okoline i konzerviranju 
okoliša/krajolika. Održavanje osnovice prirodnih resursa i gospodarenje šumama na održiv način zahtijevat će obrazovne programe koji će uključivati politiku i zakonodavstvo, poslovnu ekonomiju i gospodarenje, i šumske resurse, uključujući komponentu ekonomije okoliša.

Planiranje i oblikovanje inovativnih socio-ekonomskih nastavnih i istraživačkih programa $\mathrm{u}$ šumarstvu mora se zasnivati na specifičnostima gospodarenja obnovljivim prirodnim resursima. Fokus takvih programa treba biti na sljedećem:

- održivost kao vodeći princip za održavanje i razvoj osnovice prirodnih resursa;

- multifunkcionalna i lokalno prilagođena rješenja za gospodarenje zemljištem koja adresiraju pozornost na rastuće ekonomske, društvene i okolišne standarde;

- isprepletenost prirodnih procesa, tehnoloških rješenja, društvenih ponašanja i donošenja političkih odluka;

- poboljšanja u gospodarenju zemljištem kroz razvijanje djelotvornih institucija i uključivanje utjecajnih interesnih grupa;

- korištenje odgovarajućih instrumenata baziranih na tržištu, i koordiniranje mreže javne politike, i,

- multidisciplinarni pristup u okvirima prirodne i društvene znanosti što dovodi do zajedničke znanstvene osnovice u smislu ekonomskoga razvoja, društvenih potreba i vrijednosti, i kulturnih promjena.

Dinamika šume i okoliša rezultat je kompleksnog uzajamnog djelovanja između fizičkog i ekološkog stanja i promjenjivih utjecaja koji proizlaze iz društvenih potreba i vrijednosti, novih ekonomskih mogućnosti/prilika, i političkih institucija koje se razvijaju. Socijalni, ekonomski i politički procesi su se razvili i postali višerazinski. Ovo zahtijeva interdisciplinarni pogled na šumske sisteme koji će upućivati na mnogostruku i široko diferenciranu upotrebu obnovljivih prirodnih resursa. Sveobuhvatan nastavni i istraživački pristup neophodan je za razumijevanje višestrukih promjenjivih dimenzija relevantnih proizvoda u šumarstvu, kako lokalnih, tako i na nivou država, i međunardonome nivou, uz naglašavanje ravnoteže između privatnog i javnog, i postizanja racionalne raspodjele investicija i troškova održavanja među onima koji profitiraju iz proizvodnje drveta i usluga u prirodnome okolišu.

Nastavni i naučni rad u šumarstvu omogućuju diplomiranim studentima i budućim inženjerima šumarstva da posegnu za dinamikom kulturnih promjena i njihovim značenjem u smislu društvenih zahtjeva u pogledu šuma $i$ šumarstva uopće. Studentima je neophodno integrirajuće društveno i kulturno znanje kako bi otkrili mogućnosti $\mathrm{i}$ nove pristupe $\mathrm{u}$ upravljanju prirodnim resursima $\mathrm{u}$ specifičnim situacijama i u datome trenutku. Akademsko obrazovanje i istraživački programi u šumarstvu moraju biti učvršćeni u dubokom razumijevanju dugotrajnih kulturnih procesa koji su utjecali na rasprostranjenost šuma i njihovo korištenje kroz stoljeća. Ovo razumijevanje omogućuje šumarskim stručnjacima, pedagozima i istraživačima da steknu svijest o dinamičnom uzajamnom djelovanju čovjeka i višestrukim 
društvenim utjecajima na okoliš; na prirodne resurse i gospodarenje zemljištem. Samo kulturološki kontekst može objasniti veliku raznolikost problema i rješenja u vremenu i prostoru, kao i potrebu za razvijanjem specifičnih pristupa.

Državne politike i zakonodavstvo osiguravaju neophodni politički okvir za balansiranje privatnih $i$ državnih interesa i podložni su izmjenama kao odgovor na nove društvene zahtjeve. Više nije dovoljno obratiti pozornost samo na proizvodnju drveta, zaštitu i gospodarenje šumama. Današnji društveni zahtjevi i zahtjevi prirodnoga okoliša, kao i ciljevi politike, proširuju se na posljedice ljudskoga djelovanja na klimatske promjene, očuvanje biodiverziteta, kao i na prirodu i zaštitu okoliša/krajolika. Potrebno je obratiti pažnju na nacionalne i lokalne političke probleme, kao i na zabrinutost građana i vlada kako na kontinentalnom tako i na širokom svjetskome planu. Temeljni nov aspekt politike donošenja odluka u sferi šumarstva jeste da se jednaka pažnja mora posvetiti ekonomski efikasnoj proizvodnji drveta, socijanim i kulturnim vrijednostima, kao i zaštiti okoliša.

Osnovni nastavni predmeti za sferu politike šuma $i$ zakonodavstva u šumarstvu, savremeno koncipirani, odnose se na sljedeće šire teme:

- Konzerviranje šuma, zaštita i gospodarenje šumama su ekonomski, politički, društveni i kulturni fenomen, i održivost je osnova za gospodarenje i korištenje prirodno obnovljivih resursa.

- Značajni nesporazumi u pogledu šuma postoje između različitih privatnih i državnih interesa. Takvi konflikti odnose se na kontroverzne strategije i gospodarske ciljeve za industrijsku proizvodnju drveta, zaštitu okoline i očuvanje prirode i okoliša.

- Politika šuma kao i drugi oblici javne politike vezani za šume sačinjavaju zbir regulatornih procesa višestruko suprotstavljenih i impliciraju mnoštvo političkih arbitraža i procesa donošenja odluka između privatnih i državnih interesnih grupa za korištenje šumskih resursa.

- Politički sistem i konstitutivne vrijednosti, političke institucije i politički faktori, kao i zakoni i pravna nadležnost, osnov su za političku arbitražu i procese donošenja odluka.

Proizvodnja drveta ostaje glavna okosnica tržišne prakse u šumarstvu kao i za održivi sektor šuumarstva. Nove tehnologije pružaju mogućnosti za poboljšane produktivnosti i profita od proizvodnje drveta kroz racionaliziranje i smanjenje proizvodnih troškova, a efikasno poslovno gospodaranje mora se fokusirati na čitav lanac dodate vrijednosti između aktivnosti u šumarstvu, industrijske proizvodnje drveta i izmjene zahtjeva krajnjih korisnika na tržištu. Inovativni nastavni programi u smislu poslovanja i gospodarenja u šumarstvu će istraživati stalnu modernizaciju jedinica industrijske proizvodnje bazirane na sveobuhvatnim, isplatnim (jeftinim) strategijama. Zapravo je nepohodno stalno imati na umu da su šumarstvo i sektor drvne industrije u Evropi već visoko konkurentni na svjetskome tržištu i da se brzo šire. Ukoliko industrija uspije izgraditi sadašnjom snagom i uz eliminirnje slabosti 
koje ima, održivu drvnu proizvodnju i savremene tehnologije za obradu drveta, moći će osigurati nove proizvode i usluge krajnjim korisnicima na tržištu.

Istovremeno, potrebno je hitno generirati dodatni prihod iz utrživih okolišnih $i$ rekreacijskih dobara $i$ usluga. Studenti šumarstva i šumarski stručnjaci stoga moraju razumjeti ekonomsku i industrijsku proizvodnju drveta kao i ekonomsko i višenamjensko gospodarenje zemljištem. To se tiče faktičkih i predvidivih poslovnih prilika kao i širokoga spektra želja i preferenci sadašnjih i budućih potrošača kao pokretačke snage unutar tržišne ekonomije. Analiza se fokusira na kratkoročnu i srednjeročnu perspektivu kao i na ekonomski rast u prostornoj perspektivi koji seže od lokalne, preko nacionalne do međunarodne perspektive.

Programi u ekonomiji poslovanja u šumarstvu zahtijevaju sveobuhvatno disciplinarno utemeljenje koncepata, modela i metodologija gospodarenja i ekonomske znanosti. Oni moraju prenijeti shvatanje ekonomske proizvodnje i marketinških uvjeta u šumarstvo i sektor drvne proizvodnje. Također moraju biti utemeljeni u raspoloživoj literaturi, uz rezultate primijenjenih ekonomskih istraživanja. Razvoj poduzetničkoga duha, strateško razmišljanje, kao i sposbnost razvijanja odnosa među ljudima, osnovni su ciljevi kod prenošenja znanja studentima. Osnovna pretpostavka su krajnji korisnici na tržistu koji pokreću poslovanje, postupak gospodarenja i strateške inovativne tehnike, mjere za podsticanje konkurentne drvne proizvodnje, i novi pristup marketingu okoliša i rekreativnih usluga.

Studenti, nastavno osoblje i profesionalno osoblje trebaju razumjeti kompleksne procese upravljanja poduzećima u slobodnoj tržišnoj ekonomiji. Moraju znati kako da optimiziraju proizvodnju unutar ukupnog lanca dodate vrijednosti i da razumiju primarnu ulogu tržišta i marketinga. Istovremno trebali bi biti u stanju procijeniti opcije i ograničenja industrijske proizvodnje $u$ drvnoj industriji nasuprot multifunkcionalnim proizvodnim sistemima u šumarstvu koji osiguravaju široki spektar roba i usluga. Značajna standardna poglavlja o gospodarenju i ekonomici trebaju biti uključena u ovaj program kao i poslovna politika, ljudski potencijal i organizacioni razvoj, sistemi i metode knjigovodstva, finansiranje i ulaganja, logistika i proizvodni procesi, te strateško planiranje i kontrola.

Ekonomija resursa bavi se optimiziranjem procesa proizvodnje i potrošnje $\mathrm{s}$ dinamične i intertemporalne perspektive raspodjele. Resursni ekonomisti razvijaju modele stanja optimalne potrošnje resursa i za slučajeve korigiranja prakse potrošnje ispod optimuma. Okolišna ekonomija posebno analizira pozitivne i negativne vanjske efekte proizvodnje i potrošnje i na koji način uključiti ove eksterne faktore kako bi poboljšala procese upotrebe. Primarno se zasniva na analizi statičke raspodjele resursa koja se bavi realnom konkurentskom upotrebom resursa okoliša. Ekološka ekonomija bavi se dinamičkim sistemima u evoluciji i humanim preferencama koje odražavaju široke ekološke mogućnosti i averziju prema okolišnim ograničenjima. Vremenski okvir u kojem se procesi proučavaju kreće se između kratkih i veoma dugih; njihove skale protežu se od lokalnog na globalni nivo, i težište je na održivosti 
kao kombinaciji ekonomskih, okolišnih i društvenih faktora. Zajedno, ove tri ekonomske discipline mogu proširiti perspektivu, razumijevanje i profesionalne kvalifikacije univerzitetskih diplomaca. Njihov novi pristup unutar ekonomije postao je neophodna osnova za nastavni proces i istraživački rad na području gospodarenja održivim obnovljivim prirodnim resursima. Kombiniranjem teoretskih koncepta i metodologija $u$ istraživanje orijentirano na rješavanje problema, i nastavni pristup, pomaže studentima u razumijevanju kompleksnih i hitnih pitanja u društvu u pogledu korištenja šuma, gospodarenja ekosistemima i ulozi šume u održavanju okruženja u kojem je život moguć.

Fokus nastave je na shvatanju ekonomskih vrijednosti koje su povezane s održivom upotrebom i gospodarenjem; analizom ljudskog ponašanja prema šumama, prirodi i okruženju u ekonomskom smislu; i razvijanjem ekonomski efikasnih rješenja za široki spektar ekoloških problema, na razumljiv i znanstveno utemeljen način. Osnovni nastavni predmeti uključuju:

- Povezivanje višestrukih unakrsnih područja kao i pozitivne i negativne međuzavsinosti između ekonomskih odluka i njihovog utjecaja na prirodne okolišne procese, posebno na tlu, vodi i utjecaji na klimu;

- Intertemporalni efekti alternativne upotrebe i strategije gospodarenja na sadašnje i buduće zalihe obnovljivih prirodnih resursa;

- Ekonomske implikacije pozitivnih i negativnih vanjskih faktora u proizvodnji i potrošnji u smislu njihovoga utjecaja na ponašanje firmi i pojedinaca;

- Društveni aspekti osiguravanja javnih dobara i gospodarenje vlasništvom nad zajedničkim resursima kako bi ispunili zajedničke, ekonomnske, društvene i političke zahtjeve i poštivali kulturološki utemeljene pristupe i vjerovanja;

- Dinamika promjene privatnih i javnih zahtjeva potrošača koja se zasniva na optimizaciji kombinirane proizvodnje kroz ekonomske strategije, zaštitu i očuvanje proizvodnje;

- Identifikacija, kvantifikacija, vrednovanje i monetarizacija (unovčavanje) okolišnih, društvenih i kulturnih usluga i korist koja proizlazi iz multifunkcionalnog gospodarenja šumama, zaštite okoliša, i očuvanja prirode i krajolika.

Neophodno je shvatiti mnoge moguće interakcije između proizvodnje privatnih dobara i usluga preko šuma, u jednu ruku, i održavanja protoka javnih dobara i usluga preko šuma u drugu. Istraživanje dinamički promjenjivih odnosa između šume, krajolika $i$ društva zahtijeva empirijsku analizu i konkretno iskustvo u datom prostoru i vremenu s ciljem boljeg razumijevanja prevlađujućih institucionalnih uvjeta, tekućih političkih i društvenih procesa, i sudionika koji su uključeni. Istražujući te odnose možemo shvatiti vezu između alternativnih upotreba zemljišta na različitim prostornim skalama kao i socijane promjene koje određuju višeslojne interakcije.

$\mathrm{U}$ smislu inovacija u specifično nastavnome i istraživačkom procesu politike i ekonomije šuma, potrebmno je naglasiti sljedeće zaključke: 
- Akademsko proučavanje socio-ekonomskih aspekata u šumarskome kurikulumu mora se zasnivati na pristupu sistemima, analiziranju problema $\mathrm{u}$ šumarstvu u ukupnome kontekstu korištenja prirodnih resursa, kroz praksu održivog gospodarenja zemljištem i kroz zaštitu okoliša.

- Politika podučavanja u šumarstvu pretpostavlja čvrstu disciplinarnu osnovu u teoretskim konceptima, modelima i istraživačkim metodologijama političke znanosti. Akademski kursevi o politici šumarstva i zakonima u šumarstvu trebali bi pružiti, na primjer, sveobuhvatno razumijevanje javnog kreiranja politike, mrežu gospodarenja i višeslojne političke procese.

- Ekonomija šumarstva povezana $\mathrm{s}$ gospodarenjem privatnim i javnim zemljištem trebala bi biti fokusirana na sveobuhvatno razumijevanje poduzetničkih odluka i strategija gospodarenja. Poznavanje poslovne ekonomije, analitičkih vještina, društvene sposobnosti i sposbmost upravljanja primarni su tehnički ciljevi.

- Neophodno je da profesionalni šumari razumiju opće vrijednosti vezane za okolišne, rekeracijske, i druge usluge u krajoliku. Vodeći koncepti, teorije i metodologija istraživanja ekonomije resursa, ekonomije okoliša i ekološke ekonomije, budući su povezani s upotrebom i gospodaranjem šumama, moraju biti neizostavni dio nastavnoga plana i programa u šumarstvu.

- Društven i kulturni razvoj u modernim društvima kao i istorijska dimenzija društvenih promjena u odnosu prema šumama su integrirajući faktor akademskih programa za studnete šumarskih fakulteta. Poznavanje dinamičnih promjena u ljudskome odnosu prema šumama, prirodi i okolišu je primarni fokus nastavnoga procesa. 